\title{
Protection against the co-operative toxicity of nitric oxide and oxygen free radicals by overexpression of antioxidant enzymes in bioengineered insulin-producing RINm5F cells
}

\author{
M. Tiedge ${ }^{1}$, S. Lortz ${ }^{1}$, R. Munday ${ }^{2}$, S. Lenzen ${ }^{1}$ \\ ${ }^{1}$ Institute of Clinical Biochemistry, Hannover Medical School, Hannover, Germany \\ ${ }^{2}$ AgResearch, Ruakura Agricultural Research Centre, Hamilton, New Zealand
}

\section{Abstract}

Aims/hypothesis. The importance of different antioxidative enzymes for the defence of insulin-producing cells against the toxicity of nitric oxide (NO) was characterised in bioengineered RINm5F cells.

Methods. RINm5F insulin-producing cells stably overexpressing glutathione peroxidase (GPX), catalase $(\mathrm{CAT})$ or $\mathrm{Cu} / \mathrm{Zn}$ superoxide dismutase (SOD) were exposed to $S$-nitroso- $N$-acetyl-D,L-penicillamine (SNAP), sodium nitroprusside (SNP) and 3 morpholinosydnonimine (SIN-1), which generate both NO and reactive oxygen species, and to the polyamine/ NO, complex DETA/NO which generates NO alone. The viability of the cells was tested by the MTT assay. Results. Overexpression of antioxidant enzymes provided significant protection against the toxicity of SNAP, SNP and SIN-1, with an individual specificity related to their chemical characteristics, but was without effect upon the toxicity of DETA/NO. Cells overexpressing GPX were well protected against
SNP and SNAP, while CAT was most effective against SIN-1. SOD overexpression provided less protection against the toxicity of SNAP and SNP than overexpression of GPX but was more effective in protecting against SIN-1. Co-incubation of cells with NO donors and hydrogen peroxide or hypoxanthine and xanthine oxidase showed an overadditive synergism of toxicity.

Conclusion/interpretation. The results emphasise the importance of a synergism between $\mathrm{NO}$ and reactive oxygen species for pancreatic beta-cell death. Such a synergism has also been observed after exposure of beta cells to cytokines. The component of the toxicity that is mediated by oxygen radicals can be suppressed effectively through overexpression of CAT, GPX or SOD or both. [Diabetologia (1999) 42: 849-855]

Keywords RINm5F cells, nitric oxide, reactive oxygen species, autoimmune diabetes, antioxidative enzymes.
Received: 25 November 1998 and in revised form: 2 March 1999

Corresponding author: Dr M. Tiedge, Institute of Clinical Biochemistry, Hannover Medical School, D-30623 Hannover, Germany

Abbreviations: NO, Nitric oxide; GPX, glutathione peroxidase; NOD, non-obese diabetic; SOD, superoxide dismutase; SNP, sodium nitroprusside; SNAP, $S$-nitroso- $N$-acetyl-D,L-penicillamine; CAT, catalase; HX, hypoxanthine; XO, xanthine oxidase; MTT, 3-[4,5-dimethylthiazol-2-yl]-2,5-diphenyl tetrazolium bromide; SPER/NO, (z)-1- $\{N$-[3-Aminopropyl]- $N$-[4(3-aminopropylammonio)butyl]-amino\}-diazen-1-ium-1,2-diolate; DETA/NO, (z)-1-[2-(2-Aminoethyl)- $N$-(2-ammonioethyl)amino]diazen-1-ium-1,2-diolate; SIN-1, 3-morpholinosynonimine.
The mechanisms of beta-cell destruction in autoimmune diabetes comprise specific cell-mediated mechanisms as well as humoral factors like cytokines [1-4]. The latter initiate complex cellular signal cascades which lead to cell death through necrosis or apoptosis or both $[2,3,5,6]$. Nitric oxide (NO) which is generated in the beta cell after cytokine stimulation by the induction of NO synthase is regarded as a hallmark of beta-cell toxicity together with the generation of reactive oxygen species by a so far unknown mechanism [1, 3, 5, 7-11]. DNA damage was shown to be a critical step in NO induced toxicity, using chemical NO donors as well as cytokines [12-15]. Doubt has been expressed as to whether the toxic action of NO 
alone is sufficient to explain the phenomenon of cytokine-induced beta-cell damage $[4,16]$. Recent studies have suggested that NO toxicity involves an interaction with reactive oxygen species, possibly involving formation of the highly cytotoxic peroxynitrite through interaction of NO with superoxide $[17,18]$. Support for such a synergistic action of NO and reactive oxygen species comes from the observation that rat islets are protected against the toxicity of cytokines by extracellular antioxidants $[8,19]$ and by the glutathione peroxidase (GPX) mimic ebselen [20]. Furthermore, there is evidence that peroxynitrite is involved in beta-cell death in non-obese diabetic (NOD) mice [21] and overexpression of Mn superoxide dismutase (SOD) has been shown to protect against cytokine toxicity in INS-1 cells [22].

If a co-operative action between $\mathrm{NO}$ and reactive oxygen species is important, the weak antioxidant enzyme status of pancreatic beta cells could be an important factor in NO toxicity in these cells [23-25]. We have previously shown that overexpression of antioxidant enzymes in RINm5F insulin-producing cells provides powerful protection against reactive oxygen species $[25,26]$. In the present study we have used these bioengineered cells to investigate the protective potential of antioxidant enzymes against the toxicity of a number of chemical donors of NO. Our results show a significant protective effect of high intracellular antioxidant enzymes against the toxic effects of some, but not all, NO donors. The different protection patterns of antioxidant enzymes against the toxicity of chemical NO donors are a reflection of the individual chemical characteristics of these compounds and can provide a better understanding of the synergistic toxic action of $\mathrm{NO}$ and reactive oxygen species in the destruction of insulin-producing cells in autoimmune diabetes.

\section{Materials and methods}

Materials. Sodium nitroprusside (SNP), rhodanese, sodium thiosulphate, $S$-nitroso- $N$-acetyl-D,L-penicillamine (SNAP), $\mathrm{Cu} / \mathrm{Zn}$ SOD (from bovine liver), CAT (from bovine erythrocytes), hypoxanthine (HX), xanthine oxidase (XO), diethylenetriamine and 3-[4,5-dimethylthiazol-2-yl]-2,5-diphenyl tetrazolium bromide (MTT) were purchased from Sigma (St. Louis, Mo., USA). Spermine was from Fluka (Buchs, Switzerland). (z)-1- $\{N$-[3-Aminopropyl]- $N$-[4-(3-aminopropylammonio)butyl]-amino\}-diazen-1-ium-1,2-diolate (SPER/NO) [27] and (z)-1-[2-(2-Aminoethyl)- $N$-(2-ammonioethyl)amino]diazen-1-ium-1,2-diolate (DETA/NO) [28] were kindly provided by Dr. K.-D. Kröncke (Düsseldorf, Germany). 3-Morpholinosydnonimine (SIN-1) was kindly provided by Hoechst Marion Roussel (Frankfurt, Germany). All tissue culture equipment was from GIBCO Life Technologies (Gaithersburg, Md., USA).

Tissue culture. RINm5F tissue culture cells overexpressing CAT (RIN-CAT), GPX (RIN-GPX) and Cu/Zn SOD (RINSOD) were generated by stable transfection of the cDNAs in the pcDNA3 vector [26]. Briefly, the antioxidant enzyme activ- ities were, in control and overexpressing cells, respectively: 6 and $564 \mathrm{U} / \mathrm{mg}$ protein in CAT overexpressing cells, 0.2 and 3.9 $\mathrm{U} / \mathrm{mg}$ protein in GPX overexpressing cells, 70 and $154 \mathrm{U} / \mathrm{mg}$ protein in SOD overexpressing cells [26]. In control experiments it was confirmed that transfection with the pcDNA3 vector lacking insert did not affect the expression of the cytoprotective enzymes. Cell proliferation and MTT absorbance rate as well as insulin secretion and content of RINm5F cells remained unchanged after overexpression of cytoprotective enzymes. The cells were cultured as described [26] in RPMI 1640 medium, supplemented with $10 \mathrm{mmol} / \mathrm{l}$ glucose, $10 \%$ $(\mathrm{v} / \mathrm{v})$ fetal calf serum, penicillin and streptomycin in a humidified atmosphere at $37^{\circ} \mathrm{C}$ and $5 \% \mathrm{CO}_{2}$. Selenium $(10 \mathrm{nmol} / \mathrm{l})$ as an essential co-factor for GPX was added to the tissue culture medium of GPX-transfected cells. Selenium did not affect enzyme expression or protection against the test compounds. Control and transfected RINm5F cells were seeded at a concentration of $5 \times 10^{4}$ cells/well in $100 \mu$ culture medium in 96 well microplates and allowed to attach for a period of $24 \mathrm{~h}$ before addition of test compounds which were freshly dissolved as a $10 \times$ stock solution in phosphate buffered saline solution. All cells were incubated at $37^{\circ} \mathrm{C}$ with the test compounds.

The cells were exposed to serial concentrations of SNP in the presence of sodium thiosulphate $(5 \mathrm{mmol} / \mathrm{l})$ and rhodanese $(80 \mathrm{U} / \mathrm{ml})$ [14] and to serial concentrations of SNAP, SIN-1 and DETA/NO in RPMI 1640 medium with $10 \mathrm{mmol} / \mathrm{l}$ glucose for $18 \mathrm{~h}$. Sodium thiosulphate and rhodanese were added to the medium in SNP experiments in order to inactivate cyanide ions. The viability of RINm5F cells was not affected by the presence of these compounds. In experiments investigating synergistic effects of $\mathrm{NO}$ generating compounds and reactive oxygen species, non-transfected RINm5F cells were exposed to SIN-1 $(1 \mathrm{mmol} / \mathrm{l})$ or SNAP $(0.4 \mathrm{mmol} / \mathrm{l})$ in the presence of $\mathrm{H}_{2} \mathrm{O}_{2}(40 \mu \mathrm{mol} / \mathrm{l})$ or $\mathrm{HX} / \mathrm{XO}(50 \mu \mathrm{mol} / \mathrm{l} / 1 \mathrm{mU})$ for $18 \mathrm{~h}$. In all experiments, the viability of the cells was determined after the $18 \mathrm{~h}$ incubation period using a microplate based MTT assay [29]. Viability was expressed in per cent of the MTT absorbance in the absence of the toxic compound. In experiments investigating the effects of exogenous addition of antioxidant enzymes, $\mathrm{Cu} / \mathrm{Zn}$ SOD $(60 \mathrm{U} / \mathrm{ml})$ or CAT $(6 \mathrm{U} / \mathrm{ml})$ or both were added to the incubation medium immediately before addition of SNAP (1.6 mmol/l), SNP (1.6 mmol/l) or SIN-1 (3.5 mmol/1). Control experiments with boiled preparations of SOD and CAT were carried out in parallel. The effectiveness of inactivation by boiling was verified by measurement of the enzyme activities.

Statistical analyses. Data are expressed as mean values \pm SEM. Statistical analyses were done using the two-sided Student's $t$ test or ANOVA plus Dunnett's test for multiple comparisons. $\mathrm{EC}_{50}$ values were calculated from nonlinear regression analyses using least square algorithms of the Prism analysis program (Graphpad, San Diego, Calif., USA).

\section{Results}

\section{Cytotoxicity of $\mathrm{NO}$ donors}

SNAP. A concentration-dependent decrease of viability in non-transfected RINm5F cells was recorded, with an $\mathrm{EC}_{50}$ value for SNAP of $0.58 \mathrm{mmol} / 1$. Overexpression of GPX significantly increased cellular resistance against SNAP, resulting in an $\mathrm{EC}_{50}$ value of $1.53 \mathrm{mmol} / \mathrm{l}$. CAT overexpression was less effective 

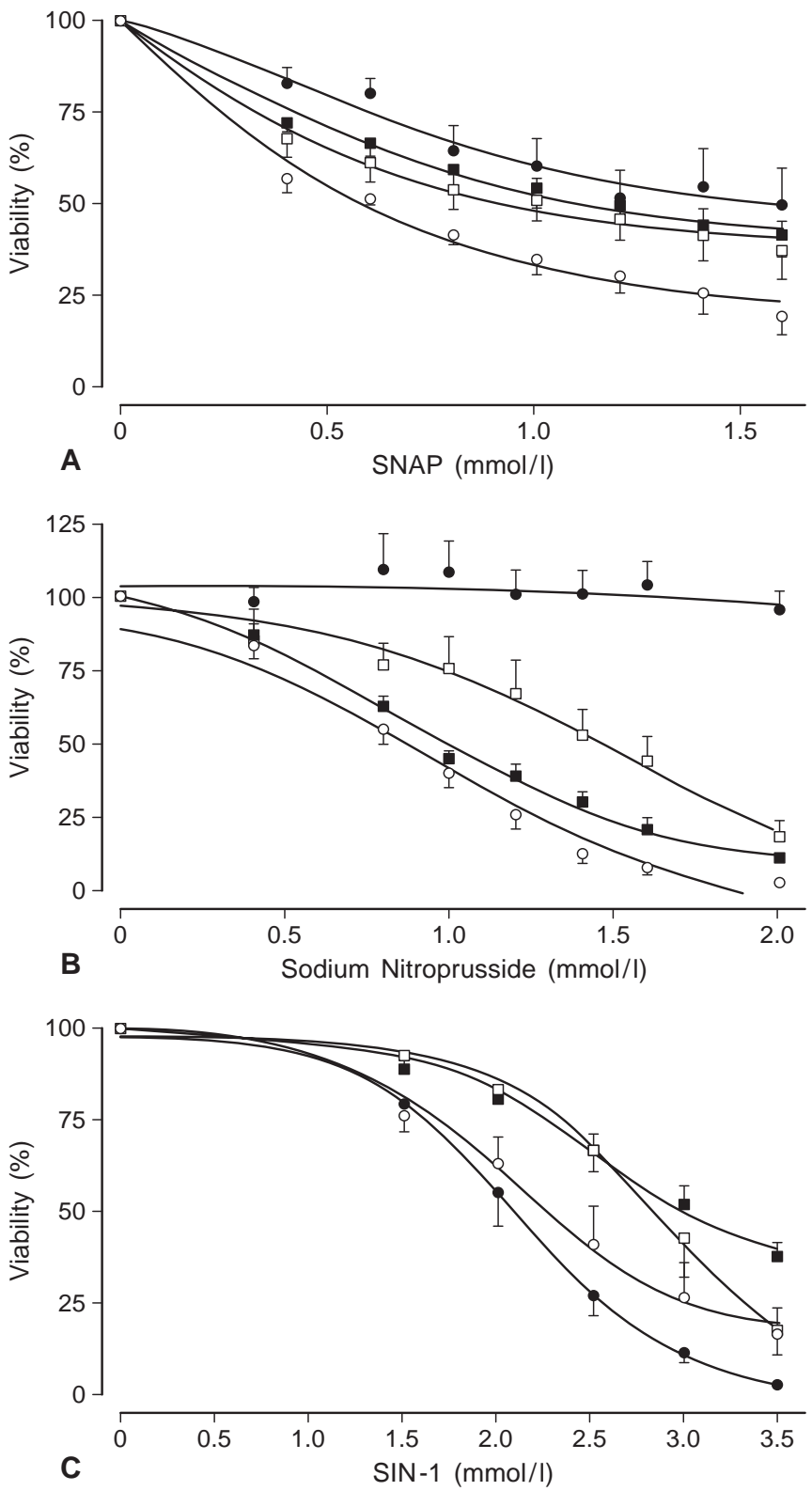

Fig.1.A-C Effects of overexpression of antioxidant enzymes in RINm5F cells on the toxicity of SNAP A, SNP B and SIN-1 C. $(\bigcirc)$ non-transfected, $(\mathbf{O})$ cells overexpressing GPX, $(\boldsymbol{\square})$ cells overexpressing CAT, $(\square)$ cells overexpressing $\mathrm{Cu} / \mathrm{Zn}$ SOD. Viability was measured by the MTT assay and expressed as $\%$ of the untreated cells. Data are given as means \pm SEM from 4-6 individual experiments

than GPX but nonetheless doubled the $\mathrm{EC}_{50}$ value compared with controls. SOD overexpression provided a small but significant protection against SNAP, with a $40 \%$ increase in the $\mathrm{EC}_{50}$ value (Fig. 1A; Table 1).

SNP. Overexpression of GPX gave excellent protection against the toxic effect of SNP, whereas overexpression of CAT was without effect. The viability of cells overexpressing GPX decreased only marginally
Table 1. Half-maximal effective concentrations $\left(\mathrm{EC}_{50}\right)$ for toxicity in the MTT assay of SNAP, SNP and SIN-1 in RINm5F cells after overexpression of various antioxidant enzymes

\begin{tabular}{llll}
\hline & SNAP $(\mathrm{mmol} / \mathrm{l})$ & \multicolumn{1}{c}{ SNP $(\mathrm{mmol} / \mathrm{l})$} & SIN-1 $(\mathrm{mmol} / \mathrm{l})$ \\
\hline Control & $0.58 \pm 0.03(5)$ & $0.98 \pm 0.09(5)$ & $2.3 \pm 0.10(6)$ \\
GPX & $1.53 \pm 0.02(5)^{\mathrm{a}}$ & $>2(5)^{\mathrm{a}}$ & $2.1 \pm 0.01(6)$ \\
CAT & $1.09 \pm 0.04(5)^{\mathrm{a}}$ & $1.03 \pm 0.08(5)$ & $3.0 \pm 0.11(6)^{\mathrm{a}}$ \\
SOD & $0.90 \pm 0.02(5)^{\mathrm{a}}$ & $1.52 \pm 0.07(6)^{\mathrm{a}}$ & $2.8 \pm 0.03(6)^{\mathrm{a}}$ \\
\hline
\end{tabular}

Cells were exposed to serial concentrations of the test compounds as used in the concentration dependencies shown in Figure 1. Viability of the cells was determined by the MTT assay. The $\mathrm{EC}_{50}$ values were calculated by nonlinear regression analyses from the curves in Figure 1. Values are means \pm SEM with the numbers of experiments in parentheses. ${ }^{\mathrm{a}} p<0.01$ cells compared with controls (ANOVA/Dunnett's test).

Table 2. Half-maximal effective concentrations $\left(\mathrm{EC}_{50}\right)$ for toxicity in the MTT assay of DETA/NO in RINm5F cells after overexpression of various antioxidant enzymes

\begin{tabular}{ll}
\hline & DETA/NO (mmol/l) \\
\hline Control & $1.25 \pm 0.18(4)$ \\
GPX & $1.14 \pm 0.19(5)$ \\
CAT & $1.30 \pm 0.33(5)$ \\
SOD & $1.25 \pm 0.34(5)$ \\
\hline
\end{tabular}

Cells were exposed to serial concentrations of the test compound as used in the concentration dependencies shown in Figure 2. Viability of the cells was determined by the MTT assay. The $\mathrm{EC}_{50}$ values were calculated by nonlinear regression analyses from the curves in Figure 2. Values are means \pm SEM with the numbers of experiments in parentheses.

even at concentrations of SNP which caused complete cell death in non-transfected controls. Due to the extraordinary resistance of these cells it was not possible to calculate an $\mathrm{EC}_{50}$ value for the cells overexpressing GPX. SOD overexpression also provided significant protection with a $50 \%$ increase in the $\mathrm{EC}_{50}$ value (Fig. 1B; Table 1).

SIN-1. The $\mathrm{EC}_{50}$ value for SIN-1 in control cells was $2.3 \mathrm{mmol} / \mathrm{l}$. More than $80 \%$ of the control cells lost their viability at concentrations between 1.5 and $3.5 \mathrm{mmol} / \mathrm{l}$ which indicates the narrow toxicity range of this compound. Cells overexpressing CAT were significantly more resistant to SIN-1 than controls, with an $\mathrm{EC}_{50}$ value of $3.0 \mathrm{mmol} / \mathrm{l}$. In contrast to SNAPand SNP-induced toxicity, overexpression of GPX provided no protection against SIN-1. Overexpression of $\mathrm{Cu} / \mathrm{Zn}$ SOD decreased the toxicity of SIN-1, with an $\mathrm{EC}_{50}$ value of $2.8 \mathrm{mmol} / \mathrm{l}$ (Fig. 1 C, Table 1).

$D E T A / N O$. The $\mathrm{EC}_{50}$ value of DETA/NO was $1.25 \mathrm{mmol} / \mathrm{l}$ (Fig. 2; Table 2). Overexpression of CAT, GPX or SOD did not protect against DETA/ NO-induced toxicity (Fig. 2; Table 2). DETA (diethylenetriamine) alone was not toxic in control experiments (data not shown). 


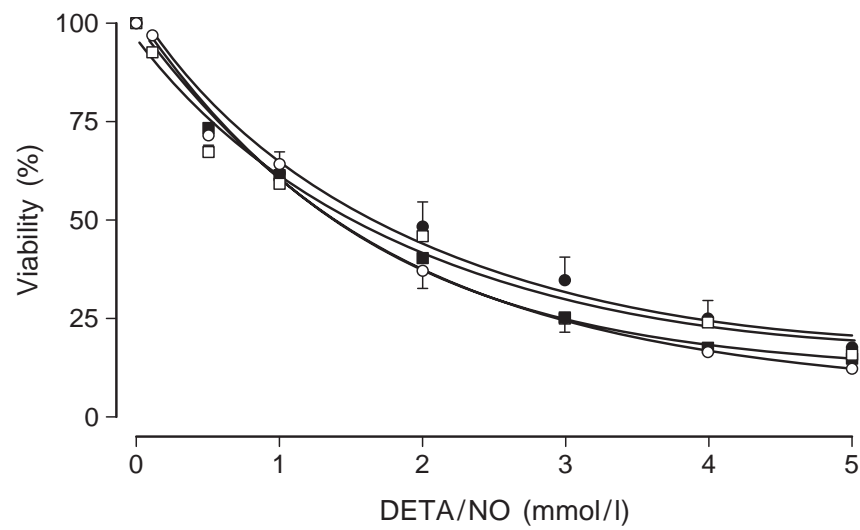

Fig. 2. Effects of overexpression of antioxidant enzymes in RINm5F cells on the toxicity of DETA/NO. (O) non-transfected, $(\mathbf{O})$ cells overexpressing GPX, $(\boldsymbol{\square})$ cells overexpressing CAT, ( $\square$ ) cells overexpressing $\mathrm{Cu} / \mathrm{Zn}$ SOD. Viability was measured by the MTT assay and expressed as \% of the untreated cells. Data are given as means \pm SEM from 4-6 individual experiments

Protective effects of exogenous antioxidant enzymes on the toxicity of $\mathrm{NO}$ donors. The addition of CAT or SOD to the culture medium, either alone or in combination, had no effect on the toxicity of SNAP, SNP or DETA/NO (Table 3). Addition of CAT or SOD alone did not significantly counteract the toxic effects of SIN-1 but addition of both enzymes provided significant protection against SIN-1 induced toxicity (Table 3 ). The protective action was not seen with enzymes that had been inactivated by boiling (data not shown).

Synergistic effects of hydrogen peroxide and $H X / X O$ on the toxicity of SIN-1 and SNAP in RINm5F control cells. RINm5F cells were exposed to low concentrations of SNAP or SIN-1 in combination with $\mathrm{H}_{2} \mathrm{O}_{2}$ or $\mathrm{HX} / \mathrm{XO}$. Incubation of non-transfected control cells with $\mathrm{H}_{2} \mathrm{O}_{2}(40 \mu \mathrm{mol} / \mathrm{l}), \mathrm{HX} / \mathrm{XO}(50 \mu \mathrm{mol} / \mathrm{l} /$ $1 \mathrm{U} / \mathrm{l})$, SNAP $(0.4 \mathrm{mmol} / \mathrm{l})$ or SIN-1 $(1 \mathrm{mmol} / \mathrm{l})$ alone for $18 \mathrm{~h}$ had little effect on cellular viability, with a maximal loss of $25 \%$ in the presence of $\mathrm{H}_{2} \mathrm{O}_{2}$
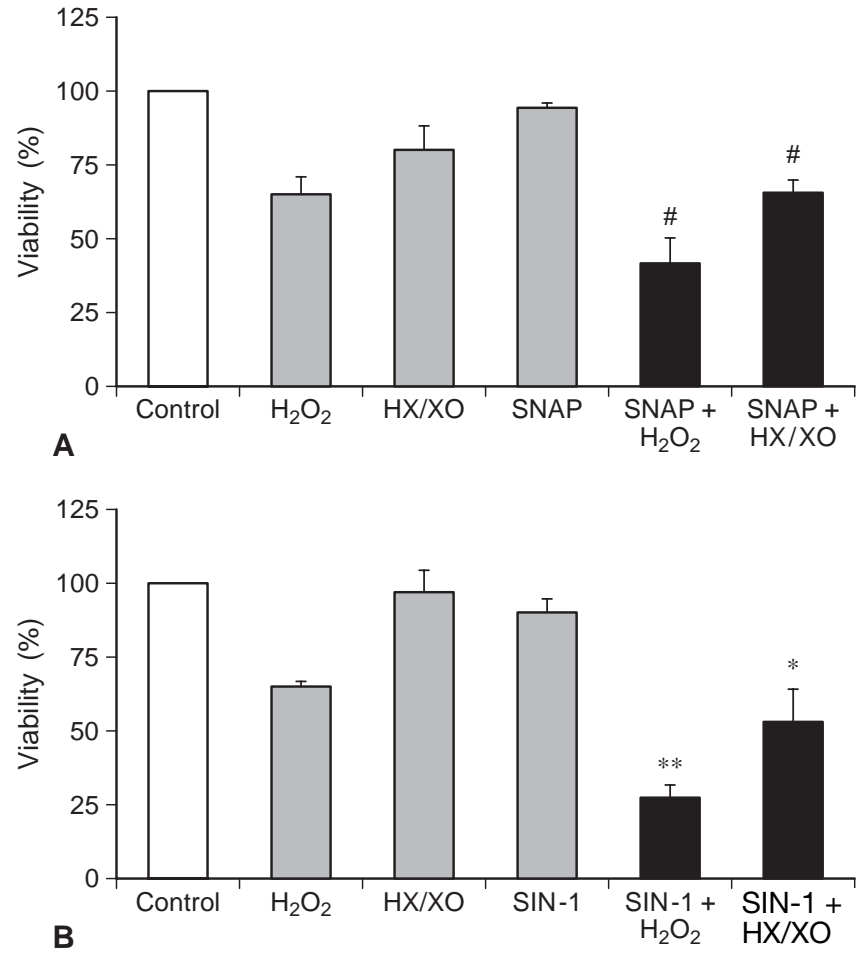

Fig.3.A, B Synergistic effects of oxygen free radical donors on the toxicity of SNAP A and SIN-1 B in RINm5F control cells. Cells were exposed to $40 \mu \mathrm{mol} / \mathrm{l}$ hydrogen peroxide $\left(\mathrm{H}_{2} \mathrm{O}_{2}\right), 50 \mu \mathrm{mol} / \mathrm{l}$ hypoxanthine plus $1 \mathrm{U} / \mathrm{l}$ xanthine oxidase (HX/XO), $0.4 \mathrm{mmol} / 1 \mathrm{SNAP}, 1 \mathrm{mmol} / \mathrm{l} \mathrm{SIN-1}$ alone or to a combination of one of the NO donors with one of the oxygen free radical donors. Viability was measured by the MTT assay and expressed as \% of the untreated cells. Data are given as means \pm SEM from 5 individual experiments. ${ }^{*} p<0.05$ compared with $\mathrm{H}_{2} \mathrm{O}_{2}$-treated cells, ${ }^{*} p<0.05$ compared with SIN-1 treated cells, ${ }^{* * *} p<0.01$ compared with $\mathrm{H}_{2} \mathrm{O}_{2}$-treated cells (Student's $t$ test)

(Fig.3). Combining SNAP with $\mathrm{H}_{2} \mathrm{O}_{2}$ or $\mathrm{HX} / \mathrm{XO}$, however, resulted in an overadditive toxic effect with an average additional increase in the toxicity of $18 \%$ for $\mathrm{H}_{2} \mathrm{O}_{2}$ and $10 \%$ for $\mathrm{HX} / \mathrm{XO}$, exceeding the sum of the average toxic effects of the single compounds (Fig.3A). The co-operative action was even more pronounced when SIN-1 was combined with $\mathrm{H}_{2} \mathrm{O}_{2}$ or

Table 3. Protective effects of catalase (CAT) and Cu/Zn SOD (SOD) added to the incubation medium of control RINm5F cells against toxicity of various NO donors

\begin{tabular}{|c|c|c|c|c|}
\hline Enzyme Addition & SNAP & SNP & $\begin{array}{l}\text { SIN-1 } \\
\text { Viability (\%) }\end{array}$ & DETA/NO \\
\hline None & $14.7 \pm 1.5(5)$ & $25.1 \pm 5.0(5)$ & $2.9 \pm 0.6(4)$ & $29 \pm 4(5)$ \\
\hline CAT & $14.0 \pm 3.0(5)$ & $24.4 \pm 5.4(5)$ & $7.5 \pm 2.0(4)$ & $31 \pm 3(5)$ \\
\hline SOD/CAT & $10.4 \pm 2.1(5)$ & $22.4 \pm 4.7(5)$ & $75.4 \pm 4.6(4)^{\mathrm{a}}$ & $33 \pm 3(5)$ \\
\hline
\end{tabular}

Non-transfected control RINm5F cells were exposed to SNAP (1.6 mmol/l), SNP (1.6 mmol/l), SIN-1 (3.5 mmol/l) or DETA/ $\mathrm{NO}(5 \mathrm{mmol} / \mathrm{l})$ in the presence of exogenous $\mathrm{Cu} / \mathrm{Zn}$ SOD $(60 \mathrm{U} / \mathrm{ml})$ and/or bovine CAT $(6 \mathrm{U} / \mathrm{ml})$. Viability of the cells was determined by the MTT assay and expressed as per cent of the untreated controls. Values are means \pm SEM with the number of experiments in parentheses. ${ }^{\mathrm{a}} p<0.01$ compared with the inhibition by the toxic compound in the absence of exogenous antioxidant enzymes (ANOVA/Dunnett's test). 
$\mathrm{HX} / \mathrm{XO}$ with overadditive toxic effects of $27 \%$ for $\mathrm{H}_{2} \mathrm{O}_{2}$ and $35 \%$ for $\mathrm{HX} / \mathrm{XO}$ (Fig. 3B).

\section{Discussion}

Nitric oxide and oxygen free radicals play an important part in the destruction of beta cells in autoimmune diabetes $[4,30,31]$ although the precise mechanism of interaction is still not known. To further clarify this issue, our study focused on the protective potential of antioxidant enzymes against the synergistic action of $\mathrm{NO}$ and oxygen free radicals using bioengineered RINm5F insulin-producing cells overexpressing CAT, GPX or SOD [26]. The NO donors SNAP, SNP and SIN-1 have been widely used in the study of the pharmacological and toxic effects of NO. They have also been shown to be toxic to beta cells $[14,15,32]$. In our study, we have also investigated the toxicity of the polyamine $\mathrm{NO}$ complex DETA/NO which generates beta-cell toxic NO without concomitant release of oxygen free radicals [12].

The Results section shows the data obtained in the experiments of the clones with the highest cytoprotective enzyme activities. To exclude an influence of a clonal variation, we studied the effects of the test compounds in two additional clones with high expression of GPX, CAT and SOD. These studies showed no significant differences in the protection against the toxicity of NO donors (data not shown).

The mechanism and specificity of NO production vary considerably among the different NO donors. SIN-1 spontaneously decomposes under aqueous conditions, generating superoxide and NO at comparable rates [33, 34]. Superoxide reacts rapidly with $\mathrm{NO}$, forming peroxynitrite [18], while any that does not react in this way will dismutate to hydrogen peroxide. Superoxide, NO, peroxynitrite and hydrogen peroxide have all been detected in incubations of SIN-1 [35, 36]. In contrast, SNP does not release NO spontaneously but is activated by one-electron reduction to the nitroxide radical anion [37]. The radical anion decays to release NO but it can also redox cycle, with concomitant generation of superoxide [38]. Nitrosothiols such as SNAP spontaneously dissociate to NO and the thiyl radical [33]. The latter, via formation of the disulphide radical anion, generates superoxide [39]. In contrast, the polyamine/NO complex DETA/NO yields NO without the formation of reactive oxygen species or other free radicals that can generate such species $[12,33]$.

We selected for the present experiments the polyamine/NO complex DETA/NO rather than SPER/NO as a pure NO donor because DETA (diethylenetriamine) after release of NO was not toxic to RINm5F cells in contrast to spermine which was toxic also by itself (unpublished observation).
Cells incubated with SIN-1, SNAP and SNP, but not with DETA/NO, will therefore be exposed not only to NO but also to reactive oxygen species and peroxynitrite. There has been much debate as to which of these are involved in the induction of the cell death provoked by NO donors. In our experiments, the importance of extracellular formation of superoxide and hydrogen peroxide by the NO donors was investigated by addition of SOD and CAT to the cell cultures, while the importance of a co-operative effect of NO and reactive oxygen species was determined by addition of hydrogen peroxide or HX/XO (which generates both hydrogen peroxide and superoxide radical) to the medium. Addition of antioxidant enzymes had no effect on the toxicity of SNP, in line with earlier observations [34], or on that of SNAP and DETA/NO, indicating that the extracellular production of reactive oxygen species does not play a major part in the toxic action of these substances. A pronounced effect was recorded with SIN-1, however, indicating that the reactive oxygen species generated by this substance make a significant contribution to its toxicity. Addition of hydrogen peroxide or $\mathrm{HX} / \mathrm{XO}$ potentiated the effects of SNAP and SIN-1 in an overadditive fashion, consistent with a synergistic action between $\mathrm{NO}$ and reactive oxygen species, as observed in other cell types [40]. Such a co-operative action of NO donors and reactive oxygen species, both of which had little effect in isolation, could be of crucial importance in mediating the toxicity of cytokines to beta cells.

The importance of intracellular formation and destruction of reactive oxygen and reactive nitrogen species was studied in RIN5mF cells expressing high levels of antioxidant enzymes. Cells transfected with SOD were more resistant than control cells to the toxic action of SIN-1, SNP, and SNAP. There are several possible mechanisms for this effect. Firstly, the protective effect of SOD could reflect a direct toxic effect of superoxide. Secondly, SOD could act by inhibiting formation of peroxynitrite. Thirdly, as suggested in a previous study [41], the reduction of NO to the nitroxyl anion $\left(\mathrm{NO}^{-}\right)$by SOD could lead to detoxification, since $\mathrm{NO}^{-}$decays to the non-toxic nitrous oxide [42]. Such a process would be expected to provide protection against all $\mathrm{NO}$ donors but under the conditions of our experiments SOD had no effect on the cytotoxicity of DETA/NO. So there is no answer to this question at the moment.

Transfection of RIN5mF cells with CAT gave significant protection against the cytotoxicity of SNAP and SIN-1. This observation could reflect the involvement of intracellularly-generated hydrogen peroxide in the toxicity of these substances or detoxification of NO via the CAT-NO complex. Nitric oxide liganded to iron is oxidised by hydrogen peroxide, forming nitrite [43], and it has been shown that NO complexed to CAT is destroyed by hydrogen peroxide [44]. Because the primary function of CAT is to de- 
stroy hydrogen peroxide, this reaction might at first seem rather implausible. Because of the low affinity of CAT for its substrate, however [45], low concentrations of this substance can exist even in the presence of high levels of the enzyme and, in view of the results of another study [44], such levels must be sufficient to destroy the CAT-NO complex. In this way NO would be detoxified through conversion to nitrite. In this context it is possibly important that hydrogen peroxide is formed by reaction of peroxynitrite with biologically relevant amino-type molecules such as ATP or nucleic acids [46].

Cells transfected with GPX were more resistant to the toxicity of SNAP and SNP than control cells. Again, this could reflect the involvement of intracellular hydrogen peroxide but it could also be attributable to the ability of GPX to detoxify peroxynitrite, converting it to nitrite [47].

The protection of pancreatic beta cells against autoimmune destruction is a crucial element of all concepts for the prevention of Type I (insulin-dependent) diabetes mellitus. The generation of $\mathrm{NO}$ and reactive oxygen species in beta cells during autoimmune attack has been shown in several studies [1, 3, 4]. Antioxidant free radical scavengers [8, 19] as well as the chemical GPX mimic ebselen [20] protected against cytokine mediated toxicity in insulinproducing cells. The protective potential of chemical antioxidants, however, is low compared with that of antioxidant enzymes. In fact transgenic mice overexpressing $\mathrm{Cu} / \mathrm{Zn}$ SOD proved to be significantly more resistant towards the diabetogenic compound alloxan [48].

We have recently shown the efficacy of optimised antioxidant enzyme levels in protecting bioengineered insulin-producing RINm5F cells against reactive oxygen species [26]. After exposure to potent oxidants such as $\mathrm{H}_{2} \mathrm{O}_{2}$ or $\mathrm{HX} / \mathrm{XO}$, these cells showed a level of antioxidative defence which could not be achieved by chemical antioxidants. This has also been confirmed recently in primary cells overexpressing CAT through an adenoviral vector system [49]. In our study, these bioengineered RINm5F cells also provided an excellent tool to investigate whether antioxidant enzymes could protect against the toxicity of NO donors. Although the mechanism of action of these enzymes is not yet completely understood, the demonstration that they can reduce the harmful effects of certain NO donors will be important in the development of future strategies trying to protect pancreatic beta cells from cytokine-mediated damage during autoimmune destruction. Evidence for the protective potential of antioxidant enzymes against cytokine-mediated toxicity has recently been provided by studies on insulin-secreting cell lines overexpressing mitochondrial Mn SOD [22]. Finally, these studies will help us to define levels of antioxidant enzymes that are optimal for the protection of insulin- secreting cells against destruction during the development of autoimmune diabetes.

Acknowledgements. This study has been supported by grants from the Juvenile Diabetes Foundation International (JDFI), New York and the Waikato Medical Research Foundation, Hamilton, New Zealand. The authors are grateful to Dr. Y.S. Ho (Detroit, Mich., USA) for kindly providing the cDNAs for GPX and Cu/Zn SOD and Dr. K.-D. Kröncke (Düsseldorf, Germany) for kindly providing SPER/NO and DETA/NO. Some of the results were obtained during thesis work by $\mathrm{St}$ Lortz.

\section{References}

1. Mandrup Poulsen T, Helqvist S, Wogensen LD, Molvig J, Pociot F, Johannesen J, Nerup J (1990) Cytokines and free radicals as effector molecules in the destruction of pancreatic beta cells. Curr Top Microbiol Immunol 164: 169-193

2. Bach JF (1994) Insulin-dependent diabetes mellitus as an autoimmune disease. Endocr Rev 15: 516-542

3. Eizirik DL, Flodstrom M, Karlsen AE, Welsh N (1996) The harmony of the spheres: Inducible nitric oxide synthase and related genes in pancreatic beta cells. Diabetologia 39: 875-890

4. Rabinovitch A, Suarez-Pinzon WL (1998) Cytokines and their roles in pancreatic islet beta-cell destruction and insulin-dependent diabetes mellitus. Biochem Pharmacol 55: 1139-1149

5. Cunningham JM, Green IC (1994) Cytokines, nitric oxide and insulin secreting cells. Growth Regul 4: 173-180

6. Delaney C, Pavlovic D, Hoorens A, Pipeleers D, Eizirik D (1997) Cytokines induce deoxyribonucleic acid strand breaks and apoptosis in human pancreatic islet cells. Endocrinology 138: 2610-2614

7. Corbett JA, Wang JL, Sweetland MA, Lancaster JR, Jr, McDaniel ML (1992) Interleukin 1 beta induces the formation of nitric oxide by beta-cells purified from rodent islets of Langerhans. Evidence for the beta-cell as a source and site of action of nitric oxide. J Clin Invest 90: 2384-2391

8. Rabinovitch A, Suarez WL, Thomas PD, Strynadka K, Simpson I (1992) Cytotoxic effects of cytokines on rat islets: evidence for involvement of free radicals and lipid peroxidation. Diabetologia 35: 409-413

9. Mandrup Poulsen T, Corbett JA, McDaniel ML, Nerup J (1993) What are the types and cellular sources of free radicals in the pathogenesis of type 1 (insulin-dependent) diabetes mellitus? Diabetologia 36: 470-471

10. McDaniel M, Kwon G, Corbett JA (1994) Role for nitric oxide in cytokine-induced pancreatic B-cell dysfunction and destruction. In: Flatt PR, Lenzen S (eds) Frontiers of Insulin Secretion and Pancreatic B-Cell Research. SmithGordon, London, pp 567-574

11. Suarez Pinzon WL, Strynadka K, Rabinovitch A (1996) Destruction of rat pancreatic islet beta-cells by cytokines involves the production of cytotoxic aldehydes. Endocrinology 137: 5290-5296

12. Kröncke KD, Brenner HH, Rodriguez ML, Etzkorn K, Noack EA, Kolb H, Kolb Bachofen V (1993) Pancreatic islet cells are highly susceptible towards the cytotoxic effects of chemically generated nitric oxide. Biochim Biophys Acta 1182: 221-229

13. Rabinovitch A, Suarez Pinzon WL, Shi Y, Morgan AR, Bleackley RC (1994) DNA fragmentation is an early event in cytokine-induced islet beta-cell destruction. Diabetologia 37: 733-738 
14. Fehsel K, Jalowy A, Qi S, Burkart V, Hartmann B, Kolb H (1993) Islet cell DNA is a target of inflammatory attack by nitric oxide. Diabetes 42: 496-500

15. Eizirik DL, Delaney CA, Green MH et al. (1996) Nitric oxide donors decrease the function and survival of human pancreatic islets. Mol Cell Endocrinol 118: 71-83

16. Welsh N, Eizirik DL, Sandler S (1994) Nitric oxide and pancreatic beta-cell destruction in insulin dependent diabetes mellitus: don't take NO for an answer. Autoimmunity 18: 285-290

17. Bartosz G (1996) Peroxynitrite: mediator of the toxic action of nitric oxide. Acta Biochim Pol 43: 645-659

18. Beckman JS, Koppenol WH (1996) Nitric oxide, superoxide, and peroxynitrite: the good, the bad, and ugly. Am J Physiol 271:C1424-C1437

19. Sumoski W, Baquerizo H, Rabinovitch A (1989) Oxygen free radical scavengers protect rat islet cells from damage by cytokines. Diabetologia 32: 792-796

20. de-Mello MA, Flodstrom M, Eizirik DL (1996) Ebselen and cytokine-induced nitric oxide synthase expression in insulin-producing cells. Biochem Pharmacol 52: 1703-1709

21. Suarez Pinzon WL, Szabo C, Rabinovitch A (1997) Development of autoimmune diabetes in NOD mice is associated with the formation of peroxynitrite in pancreatic islet betacells. Diabetes 46: 907-911

22. Hohmeier HE, Thigpen A, Tran VV, Davis R, Newgard CB (1998) Stable expression of manganese superoxide dismutase (MnSOD) in insulinoma cells prevents IL-1beta-induced cytotoxicity and reduces nitric oxide production. J Clin Invest 101: 1811-1820

23. Grankvist K, Marklund SL, Taljedal IB (1981) CuZnsuperoxide dismutase, Mn-superoxide dismutase, catalase and glutathione peroxidase in pancreatic islets and other tissues in the mouse. Biochem J 199: 393-398

24. Lenzen S, Drinkgern J, Tiedge M (1996) Low antioxidant enzyme gene expression in pancreatic islets compared with various other mouse tissues. Free Radic Biol Med 20: 463-466

25. Tiedge M, Lortz S, Drinkgern J, Lenzen S (1997) Relation between antioxidant enzyme gene expression and antioxidative defense status of insulin-producing cells. Diabetes 46: $1733-1742$

26. Tiedge M, Lortz S, Munday R, Lenzen S (1998) Complementary action of antioxidant enzymes in the protection of bioengineered insulin-producing RINm5F cells against the toxicity of reactive oxygen species. Diabetes 47: $1578-1585$

27. Maragos CM, Morley D, Wink DA et al. (1991) Complexes of NO with nucleophiles as agents for the controlled biological release of nitric oxide. Vasorelaxant effects. J Med Chem 34: 3242-3247

28. Shimaoka M, Iida T, Ohara A, Taenaka N, Mashimo T, Honda T, Yoshiya I (1995) NOC, a nitric-oxide-releasing compound, induces dose dependent apoptosis in macrophages. Biochem Biophys Res Commun 209: 519-526

29. Mosmann T (1983) Rapid colorimetric assay for cellular growth and survival: application to proliferation and cytotoxicity assays. J Immunol Methods 65: 55-63

30. Corbett JA, McDaniel ML (1992) Does nitric oxide mediate autoimmune destruction of beta-cells? Possible therapeutic interventions in IDDM. Diabetes 41: 897-903
31. Eizirik DL (1996) Beta-cell defence and repair mechanisms in human pancreatic islets. Horm Metab Res 28: 302-305

32. Delaney CA, Green IC, Lowe JE et al. (1997) Use of the comet assay to investigate possible interactions of nitric oxide and reactive oxygen species in the induction of DNA damage and inhibition of function in an insulin-secreting cell line. Mutat Res 375: 137-146

33. Feelisch M, Stamler JS (1996) Donors of nitrogen oxides. In: Methods in Nitric Oxide Research, Wiley, New York, pp 71-115

34. Ioannidis I, de Groot H (1993) Cytotoxicity of nitric oxide in Fu5 rat hepatoma cells: evidence for co-operative action with hydrogen peroxide. Biochem J 296: 341-345

35. Quine LA, Carrier MJ, Anggard EE (1997) Effect of antioxidants on the degradation of SIN-1. Biochem Soc Trans 25: $417 \mathrm{~S}$

36. Hogg N, Darley-Usmar VM, Wilson MT, Moncada S (1992) Production of hydroxyl radicals from the simultaneous generation of superoxide and nitric oxide. Biochem J 281: 419-424

37. Rao DN, Elguindi S, O'Brien PJ (1991) Reductive metabolism of nitroprusside in rat hepatocytes and human erythrocytes. Arch Biochem Biophys 286: 30-37

38. Ramakrishna Rao DN, Cederbaum AI (1996) Generation of reactive oxygen species by the redox cycling of nitroprusside. Biochim Biophys Acta 1289: 195-202

39. Munday R (1994) Bioactivation of thiols by one-electron oxidation. Adv Pharmacol 27: 237-270

40. Filep JG, Lapierre C, Lachance S, Chan JS (1997) Nitric oxide co-operates with hydrogen peroxide in inducing DNA fragmentation and cell lysis in murine lymphoma cells. Biochem J 321: 897-901

41. Murphy ME, Sies H (1991) Reversible conversion of nitroxyl anion to nitric oxide by superoxide dismutase. Proc Natl Acad Sci USA 88: 10860-10864

42. Bonner FT (1996) Nitric oxide gas. Methods Enzymol 268: 50-57

43. Kanner J (1996) Nitric oxide and metal-catalyzed reactions. Methods Enzymol 269: 218-229

44. Brunelli L, Koppenol WH, Bertolini A, Beckman JS (1994) Catalase can scavenge nitric oxide. Circulation 90: I-458 (Abstract)

45. Halliwell B, Gutteridge JMC (1995) Free radicals in biology and medicine, 2nd edn. Clarendon Press, Oxford

46. Kirsch M, Lomonosova EE, Korth HG, Sustmann R, de Groot H (1998) Hydrogen peroxide formation by reaction of peroxynitrite with HEPES and related tertiary amines. Implications for a general mechanism. J Biol Chem 273: 12716-12724

47. Sies H, Sharov VS, Klotz LO, Briviba K (1997) Glutathione peroxidase protects against peroxynitrite-mediated oxidations. A new function for selenoproteins as peroxynitrite reductase. J Biol Chem 272: 27812-27817

48. Kubisch HM, Wang J, Luche R, Carlson E, Bray TM, Epstein CJ, Phillips JP (1994) Transgenic copper/zinc superoxide dismutase modulates susceptibility to type I diabetes. Proc Natl Acad Sci USA 91: 9956-9959

49. Benhamou PY, Moriscot C, Richard MJ et al. (1998) Adenovirus-mediated catalase gene transfer reduces oxidant stress in human, porcine and rat pancreatic islets. Diabetologia 41: 1093-1100 